\title{
Івашньова C.,
}

заступник директора Інституту післядипломної освіти

Київського університету імені Бориса Грінченка,

кандидат педагогічних наук

s.ivashnova@kubg.edu.ua

ORCID iD 0000-0002-4805-007x

\section{БЕЗПЕРЕРВНИЙ ПРОФЕСІЙНИЙ РОЗВИТОК ЯК ТРУДОВА ФУНКЦІЯ ПЕДАГОГА}

Стаття презентує результати теоретичного дослідження змісту й сутності терміна «трудова функція» та опитування педагогів у форматі фокус-груп. Аналіз змісту поняття «безперервний професійний розвиток» і динаміки його змін протягом професійного життя педагога дав змогу виокремити провідні компетентності, включені до змісту трудової функції. Дальше обговорення змісту та сутності трудової функції «безперервний професійний розвиток» продемонструвало наявність певних утруднень, які відчувають опитувані при визначенні ключових компетентностей, та згода щодо важливості професійного розвитку в діяльності вчителя. Опитування виявило також усвідомлення респондентами існування певних ризиків з огляду на те, що норми професійного стандарту матимуть односторонній характер, тобто трактуватимуться лише як нові вимоги до вчителя та не враховуватимуть зміну вимог до роботодавця.

Подальщого дослідження потребують результати впровадження проєкту професійного стандарту та перегляд діяльності системи підвищення кваліфікації педагогів.

Ключові слова: безперервний професійний розвиток, здатність до навчання впродовж життя, компетентність, професія, реслективна компетентність, трудова функція.

(c) Івашньова С., 2021

(с) Київський університет імені Бориса Грінченка, 2021

Вступ. Проєкт Професійного стандарту за професіями «Вчитель початкових класів закладу загальної середньої освіти» та «Вчитель закладу загальної середньої освіти» (далі Професійний стандарт) запропоновано для загальнонаціонального обговорення 5 травня 2020 р. Документ містить вимоги до вчителів початкової школи та вчителів-предметників, що здійснюють професійну освітню діяльність у закладах загальної середньої освіти, і створений на основі компетентнісного підходу; описує основні трудові функції та умови праці вчителів; встановлює єдині вимоги до їхніх загальних і фахових компетентностей відповідно до кваліфікаційної категорії та умови допуску до роботи.

Розроблення такого документа створює нові можливості як для педагогів, так і для роботодавців та є основою для нейтралізації низки суперечностей між новими вимогами до педагогічного працівника, оновленим змістом професійної компетентності останнього й застарілими підходами до оцінки рівня його кваліфікації, закладені в чинному положенні про атестацію. На думку М. Ілляхової [7, с. 56], перед системою освіти стоїть базове завдання розроблення сучасної моделі безперервної освіти у контексті запитів інноваційного, інтернаціонального суспільства, перспектив розвитку національної економіки та глобальних технологічних змін. Однак створення такої моделі можливе за умови наявності професійного стандарту вчителя та суспільної згоди у трактуванні основних термінів і понять, що унеможливить суб'єктивізм щодо педагога й порушення його прав.

Проєкт документа пройшов низку обговорень та доопрацювань з урахуванням пропозицій зацікавлених сторін. Цей процес засвідчив той факт, що визначення цілої низки термінів та понять, якими оперують подібні документи, викликає певний опір частини респондентів. До цього переліку насамперед належить поняття «трудова функція», яке безпосередньо пов'язане з такими загальними термінами, як «професія», «спеціальність», «кваліфікація», «робота».

Мета статті - дослідити зміст та сутність поняття «трудова функція» на теоретичному рівні, визначити основні складові трудової функції вчителя «безперервний професійний розвиток» і презентувати результати опитування педагогів у форматі фокус-груп.

У Національному класифікаторі України [11] подано такі визначення понять, зазначених вище.

Робота - певні завдання та обов'язки, що виконані, виконуються чи повинні бути виконані однією особою. Робота є статистичною одини- 
цею, яка класифікується відповідно до кваліфікації, необхідної для ії виконання.

Квалібікація - здатність виконувати завдання та обов'язки відповідної роботи. Кваліфікація визначається рівнем освіти та спеціалізацією.

Спеціалізація пов'язана як 3 необхідною галуззю знань, використовуваними інструментами чи устаткуванням, так і з продукцією, яка виробляється, або надаваними послугами і відповідає певною мірою деталізованому колу професійних завдань та обов'язків.

Професія - здатність виконувати такі роботи, які вимагають від особи певної кваліфікації.

На думку О.Є. Костюченка, всі ці поняття взаємозалежні: зміст трудової функції впливає на визначення виду роботи та ії складність; складність роботи залежить від кваліфікації і впливає на розмір зарплати; кваліфікація впливає на вид дорученої працівнику роботи. Таким чином, визначення змісту трудової функції працівника повинно бути індивідуалізовано [9, с. 356]. Разом з тим у колі фахівців з трудового права не припиняються дискусії щодо співвідношення змісту зазначених понять та їх ієрархії, а питання про зміст і структуру трудової функції працівника залишається в трудовому праві одним із найбільш дискусійних і складних (О.В. Лавріненко [10, с. 302]).

Науковці, сферою інтересів яких $€$ наукове право, вважають, що чітке визначення трудової функції $\epsilon$ обов'язковою умовою для трудового договору. О. Гевел підкреслює, що трудова функція має чи не найбільше значення в системі трудових правовідносин, оскільки є своєрідним стрижнем, навколо якого згуртовано всі інші елементи трудових зв'язків (які, власне, й визначаються в змісті трудового договору при встановленні взаємних прав та обов'язків) [3, с. 91].

Трудова функція є сукупністю двох ключових компонентів: по-перше, встановлених державою вимог до певної професії, тобто певних характеристик конкретної роботи, яка виконуватиметься працівником; по-друге, наявністю фізичних, освітніх, професійних, ділових, моральних, психологічних тощо навичок та умінь працівника, які 6 відповідали можливості займатись певною професією і виконувати конкретну роботу [8].

Вважаємо за потрібне зазначити, що конкретизація трудової функції має важливе практичне значення, адже прийнятий на роботу фахівець повинен не лише виконувати роботу, обумовлену трудовою угодою та окреслену в посадовій інструкції, а й має право вимагати від власника (або керівника) iї надання і створення відповідних умов.

М.Д. Бойко зазначає, що спеціальність є «частиною трудової діяльності в межах певної профеciï, що найбільш глибоко та всебічно опанована працівником. Спеціальність є основною ознакою, що характеризує трудову функцію працівника, оскільки вона містить у собі спеціалізацію працю- ючих за професіями зі специфікою роботи в умовах певного виду діяльності (наприклад, учитель фізики, лікар-терапевт, водій автомобіля, слюсар, сантехнік). Але для визначення конкретної роботи, яку буде виконувати працівник, - зазначає автор, - необхідно враховувати також кваліфікацію працівника» [2, с. 111].

Професійний стандарт вчителя важливий з огляду на диференціацію змісту трудової функції відповідно до рівнів кваліфікації, що створює підгрунтя для чіткого визначення кола професійних обов'язків у тексті трудового договору, персоналізованої посадової інструкції з урахуванням рівня кваліфікації конкретного фахівця. Конкретизація трудової функції вчителя закладу загальної середньої освіти у професійному стандарті є підставою для визначення чіткого кола прав та обов'язків педагогів, забезпечує не лише правильну організацію праці, а й окреслює напрями професійного зростання. Власник або уповноважений ним орган не має права делегувати або доручати вчителю ті завдання, які не передбачені професійним стандартом та не входять до переліку його трудових функцій, не має права змінювати трудову функцію без згоди працівника та без наявності у нього відповідної кваліфікації. Базовою трудовою функцією, що забезпечує професійне зростання вчителя, є безперервний професійний розвиток, зміст якого вперше внормовано на рівні професійного стандарту. Сутність та зміст поняття «безперервний професійний розвиток» визначались на основі аналізу актуальних досліджень у галузі педагогіки та андрагогіки, кращих вітчизняних і світових практик, міжнародних документів.

Стратегія й тактика реалізації концепції безперервної освіти окреслена у таких нормативноправових документах та проєктах документів, як Закон України «Про освіту», Державна національна програма «Освіта» (Україна XXI століття), Національна доктрина розвитку освіти, Національна стратегія розвитку освіти в Україні на 2012-2021 рр., Концепція розвитку неперервної педагогічної освіти. Зокрема, у проєкті Концепції розвитку педагогічної освіти (2018) зазначено, що безперервний професійний розвиток може здійснюватися шляхом формальної, неформальної та інформальної освіти.

Міжнародні дослідження переважно визначають безперервний професійний розвиток викладача (Continuing Professional Development - CPD) як постійний процес розвитку професійних знань, навичок та цінностей 3 допомогою кваліфікованих фахівців як на робочому місці, так і за його межами [1, с. 5]. Закон України «Про освіту» трактує безперервний професійний розвиток як «безперервний процес навчання та вдосконалення професійних компетентностей фахівців після здобуття вищої та / або післядипломної освіти, що дає змогу фахівцю підтримувати або 
покращувати стандарти професійної діяльності і триває впродовж усього періоду його професійної діяльності» [12].

У Законі України «Про освіту» [12] безперервний професійний розвиток визначається як «безперервний процес навчання та вдосконалення професійних компетентностей фахівців після здобуття вищої та / або післядипломної освіти, що дає змогу фахівцю підтримувати або покращувати стандарти професійної діяльності і триває впродовж усього періоду його професійної діяльності». «Енциклопедія освіти» визначає професійний розвиток як «процес формування суб'єкта професійної діяльності, тобто систему певних властивостей в умовах неперервної професійної освіти, самовиховання та здійснення професійної діяльності [4, с. 733]. У процесі професійного розвитку особистість оволодіває системою професійно важливих якостей, до якої входять комунікативні, мотиваційні, характерологічні, рефлексивні, освітні, інтелектуальні, психофізіологічні властивості людини».

На думку М. Ілляхової [7] «освіта впродовж життя грунтується на ідеї безперервного усунення невизначеності статусу фахівця у динаміці пізнавальних і діяльнісних практик протягом усього життя, а також розкритті його креативних ресурсів, що формуватимуть нові горизонти його професійної і особистісно орієнтованої життєдіяльності».

В описі трудової функції «безперервний професійний розвиток» проєкту Професійного стандарту виокремлено низку професійних компетентностей, знань, умінь, навичок, якими має володіти вчитель закладу загальної середньої освіти незалежно від фаху, кваліфікаційної категорії та інших індивідуальних професійних характеристик. До переліку включено інноваційну компетентність, здатність до навчання впродовж життя та рефлексивну компетентність, зміст яких розкривається і деталізується в таблицях 6 та 7 проєкту Професійного стандарту за професіями «Вчитель початкових класів закладу загальної середньої освіти», «Вчитель закладу загальної середньої освіти», «Вчитель 3 початкової освіти (з дипломом молодшого спеціаліста)».

Інноваційна компетентність вчителя передбачає наявність чітко окреслених компетентностей та знань, які лежать в основі формування компетентності. Оскільки одним із важливих професійних завдань вчителя $\epsilon$ формування наукового світогляду учнів, вважаємо, що наявність у педагога знань щодо того, якими $€$ наукові методи пізнання, здатності застосовувати ці знання в освітньому процесі, повною мірою відповідає його професійним завданням незалежно від рівня кваліфікації. У цьому контексті вимога щодо застосування наукових методів пізнання (спостереження, аналізу, формулювання гіпотез, збору, аналізу та інтерпретації даних, створення моделей і визначення дієвості) $€$ логічною, так само як і закладена розробниками документа вимога щодо вміння застосовувати «інновації у професійній діяльності» й «різноманітні підходи до розв'язання проблем у педагогічній діяльності». Вчитель, здатний аналізувати інформацію щодо освітніх інновацій, умов їх упровадження, може обгрунтувати власну професійну позицію щодо можливостей та меж інтеграції тих чи тих інновацій як у свою методичну систему, так і в систему діяльності закладу загальної середньої освіти. Педагог повинен уміти в разі необхідності адаптувати інновації до реальних умов освітнього процесу з урахуванням особливостей діяльності закладу освіти та індивідуальних потреб учнів. Така позиція не лише визначає певні вимоги до вчителя, а й убезпечує його, учнів та заклад освіти від некритичного впровадження всіх методичних новинок і забезпечує професійну свободу педагога, адже йдеться насамперед про інтеграцію інновацій у його власну методичну систему та захист інтересів здобувачів освіти.

Важливою складовою інноваційної компетентності є здатність застосовувати різноманітні підходи до вирішення проблем у педагогічній діяльності. Чи $€$ така вимога унікальною, новою чи екстраординарною? Однозначно - ні. Відповідно до даних, наведених у таблиці 6 Професійного стандарту, вчитель має знати та застосовувати методи «виявлення проблем у педагогічній діяльності, визначення характеру та причин їх появи» й «роботи з різними джерелами інформації з метою розв'язання проблем i запобігання їм». Вміння працювати 3 фаховою літературою формується під час здобуття професійної освіти і не втрачає свого значення протягом всього професійного життя фахівця. У роботі вчителів це вміння має визначальний характер, адже саме завдяки йому забезпечується самоосвітня діяльність педагога. Уточнення змісту трудової функції відбувається за рахунок чіткого переліку вмінь, на основі яких формується відповідна компетентність. У цьому разі вчитель повинен вміти «аналізувати різноманітні підходи до розв'язання проблем у педагогічній діяльності й запобігання їм, визначати наслідки реалізації альтернативних підходів», а також «визначати якість інформаційних джерел; збирати, систематизувати та використовувати інформацію, що є важливою для розв'язання проблем і запобігання їм».

Професійна компетентність «здатність до навчання впродовж життя» розкривається в проєкті професійного стандарту через «здатність визначати умови та ресурси професійного розвитку впродовж життя» і «здатність взаємодіяти з іншими вчителями на засадах партнерства та підтримки (у рамках наставництва, супервізії, інтервізії тощо)». У процесі обговорення саме остання позиція викликала дискусію через вживання термінів «супервізія» та «інтервізія». Учасники про- 
понували вилучити їх через те, що ними послуговується психологічна служба. Однак вважаємо за потрібне зазначити, що застосування педагогічної супервізії та інтервізії не лише обгрунтоване низкою наукових досліджень і поширене в зарубіжній практиці, а й передбачається чинним законодавством. Очевидно, що введення в широкий обіг цих понять вимагає грунтовного роз'яснення з боку науковців і законодавця, а від педагогів ознайомлення з практикою педагогічної супервізії та інтервізії, накопиченою, зокрема, освітніми тренерами [6] і тренерами Нової української школи [5]; формування власного досвіду та оцінювання ефективності їх застосування.

Не менш важливою у складі трудової функції «безперервна професійна освіта» $€$ рефлексивна компетентність, яка описується як «здатність здійснювати моніторинг власної педагогічної діяльності і визначати індивідуальні професійні потреби». В. Раскалінос [13, с. 181] зазначає, що рівень професійної компетентності фахівця значною мірою залежить не тільки від ступеня усвідомлення ним професійних обов'язків, а й від його здібності до самопізнання, самовдосконалення. Рефлексивна компетентність розглядається авторкою як детермінанта соціалізації особистості, механізм професійної та соціальної ідентичності. За визначенням С. Степанова, рефлексивна компетентність - це «професійна якість особистості, яка дає змогу ефективно та адекватно здійснювати рефлексивні процеси, реалізацію рефлексивної здатності, що забезпечує розвиток і саморозвиток, сприяє творчому підходу в професійній діяльності, досягненню іiі максимальної ефективності та результативності» [14].

У цьому контексті важливим $є$ саме здатність здійснювати моніторинг власної педагогічної діяльності й визначати індивідуальні професійні потреби, основу яких складають знання та вміння (табл. 1).

Таблиияя 1

Зміст рефлексивної компетентності (здатності, знання, вміння та навички)

\begin{tabular}{|c|c|}
\hline \multicolumn{2}{|c|}{ Рефлексивна компетентність } \\
\hline \multicolumn{2}{|c|}{ Здатність здійснювати моніторинг власної педагогічної діяльності й визначати індивідуальні професійні потреби } \\
\hline Знання & Вміння та навички \\
\hline Механізм моніторингу професійної діяльності вчителя & Здійснювати моніторинг власної педагогічної діяльності \\
\hline Загальні та професійні компетентності вчителя & \multirow{2}{*}{$\begin{array}{l}\text { Визначати відповідність власних загальних і професійних } \\
\text { компетентностей чинним вимогам }\end{array}$} \\
\hline $\begin{array}{l}\text { Вимоги до професійної діяльності вчителя з урахуванням } \\
\text { змін в освітній політиці, стандартах освіти }\end{array}$ & \\
\hline $\begin{array}{l}\text { Особливості діяльності закладу освіти, учнівського } \\
\text { колективу }\end{array}$ & $\begin{array}{l}\text { Враховувати зміни в системі освіти, їі законодавчому } \\
\text { забезпеченні, у діяльності закладу освіти, учнівському } \\
\text { колективі під час планування професійного розвитку }\end{array}$ \\
\hline
\end{tabular}

Така деталізація змісту здатностей, знань, умінь та навичок дасть змогу чітко та однозначно описувати вимоги до випускників закладів вищої освіти й претендентів на вакантні посади, вичерпно описувати зміст професійних обов'язків відповідно до займаної посади в посадових інструкціях та проводити (само)оцінювання рівня професійної компетентності з метою планування подальшого професійного розвитку. Процедура атестації педагогічних працівників та їхньої сертифікації має здійснюватися згідно 3 професійним стандартом, що унеможливить висування необгрунтованих вимог до вчителя або їх заниження. Динаміку змін професійної компетентності «здатність до навчання впродовж життя» подано в табл. 2.

Таблиия 2

\section{Зміст професійної компетентності «здатність до навчання впродовж життя» (за кваліфікаційними категоріями педагогічних працівників)}

\begin{tabular}{|c|c|c|c|c|}
\hline \multirow{2}{*}{$\begin{array}{l}\text { Професійна } \\
\text { компетентність }\end{array}$} & \multicolumn{4}{|c|}{ Кваліфікаційні категорії педагогічних працівників } \\
\hline & Спеціаліст & $\begin{array}{l}\text { Спеціаліст другої } \\
\text { категорії }\end{array}$ & $\begin{array}{l}\text { Спеціаліст першої } \\
\text { категорії }\end{array}$ & $\begin{array}{l}\text { Спеціаліст вищої } \\
\text { категорії }\end{array}$ \\
\hline \multirow{3}{*}{$\begin{array}{l}\text { Д2. Здатність } \\
\text { до навчання впродовж } \\
\text { життя } \\
\text { Д21. Здатність } \\
\text { визначати умови } \\
\text { та ресурси } \\
\text { професійного } \\
\text { розвитку впродовж } \\
\text { життя }\end{array}$} & $\begin{array}{l}\text { Визначає } \\
\text { операційні цілі } \\
\text { підвищення фахової } \\
\text { майстерності } \\
\text { відповідно } \\
\text { до власних } \\
\text { професійних потреб }\end{array}$ & $\begin{array}{l}\text { Визначає } \\
\text { стратегічні } \\
\text { й оперативні цілі } \\
\text { підвищення фахової } \\
\text { майстерності } \\
\text { відповідно } \\
\text { до власних } \\
\text { професійних потреб }\end{array}$ & $\begin{array}{l}\text { Визначає чіткі } \\
\text { цілі власного } \\
\text { професійного розвитку; } \\
\text { використовує практики } \\
\text { взаємонавчання } \\
\text { для підвищення фахової } \\
\text { майстерності }\end{array}$ & $\begin{array}{l}\text { Визначає цілі власного } \\
\text { професійного розвитку } \\
\text { з урахуванням цілей } \\
\text { і напрямів розвитку } \\
\text { освітньої політики, } \\
\text { бере активну участь } \\
\text { у діяльності професійних } \\
\text { спільнот }\end{array}$ \\
\hline & \multicolumn{4}{|c|}{ Планує власний професійний розвиток відповідно до визначених цілей } \\
\hline & \multicolumn{4}{|c|}{$\begin{array}{l}\text { Добирає види, форми, програми та суб’єктів підвищення кваліфікації відповідно до власних } \\
\text { професійних потреб }\end{array}$} \\
\hline
\end{tabular}


У процесі обговорення Професійного стандарту, у тому числі в соціальних мережах, висловлювались пропозиції щодо уточнення окремих визначень, вилучення певних функцій, скорочення документа тощо. У цьому контексті ми вважали за необхідне визначити, як саме розуміють педагоги зміст поняття «трудова функція» в цілому та ідентифікують складові, закладені розробниками професійного стандарту в трудовій функції «безперервний професійний розвиток». Таке дослідження було здійснене із використанням методу фокус-груп, який застосовується 3 метою уточнення позиції цільової аудиторії з того чи того питання, у тому числі - для уточнення сприйняття цільовою аудиторією змісту та сутності певних понять [5].

Всього в опитуванні взяло участь 45 осіб. Вибірка складалась 3 педагогічних працівників, розподіл яких за основними демографічними показниками (вік, стать, стаж роботи тощо) відповідав розподілу генеральної сукупності. Педагогічні працівники, які брали участь в опитуванні, мали стаж роботи 15 та більше років; 3 них 39 осіб - жінки, 6 осіб - чоловіки. Демографічний склад, рівень професійної кваліфікації та досвід навчання дорослих дає змогу ідентифікувати вибірку як таку, що відповідає особливостям генеральної сукупності (педагогічні працівники).

Для проведення опитування були сформовані 3 групи респондентів. Кожна 3 них протягом 45 хв обговорювала зміст описаної в проєкті Професійного стандарту вчителя трудової функції «безперервний професійний розвиток». Фіксація перебігу обговорення здійснювалася за допомогою цифрового диктофона, далі аудіозапис розшифровувався й здійснювався аналіз текстової версії обговорення за допомогою програми Atlas.ti (5.0). Результати обговорення були систематизовані, узагальнені та представлені у вигляді табл. 3.

Таблиия 3

Зміст трудової функції «безперервний професійний розвиток вчителя» ( за результатами опитування педагогів)

\begin{tabular}{|c|c|c|}
\hline Респондент & Зміст висловлювання & Компетентність \\
\hline R1G1 & $\begin{array}{l}\text { На мою думку, трудова функція - це комплекс дій, а не одна дія. По суті, це те, що може } \\
\text { бути записане в посадових обов’язках одним рядком. Та насправді з безперервним } \\
\text { професійним розвитком це не так, бо мають бути певні знання: що таке професійний } \\
\text { розвиток вчителя, як він здійснюється, що є показником. Якщо я старанно читаю } \\
\text { методичну літературу і відвідую тренінги - це професійний розвиток? Як його } \\
\text { виміряти? Як ця література змінює мою роботу, ті уроки, які я проводжу? }\end{array}$ & $\begin{array}{l}\text { Здатність визначати } \\
\text { умови та ресурси } \\
\text { професійного розвитку } \\
\text { впродовж життя }\end{array}$ \\
\hline R3G1 & $\begin{array}{l}\text { Я попередньо уважно прочитала проєкт стандарту, бо хотіла для себе зрозуміти, що ми } \\
\text { будемо обговорювати, і скласти власну думку. Мене в трудовій функції «безперервний } \\
\text { професійний розвиток» трохи зачепила вимога для вищої кваліфікаційної категорії } \\
\text { брати участь у розвитку професійних спільнот. Мені не зрозуміло, яких саме. У нас } \\
\text { сьогодні купа спільнот у соціальних мережах, де вчителі обмінюються думками, } \\
\text { матеріалами, обговорюють якість ситуації, але це не громадські організації з офіційним } \\
\text { статутом. Я, наприклад, можу створити таку спільноту, але чи відповідатиме це тим } \\
\text { вимогам, аби визнати мою діяльність? }\end{array}$ & $\begin{array}{l}\text { Здатність визначати } \\
\text { умови та ресурси } \\
\text { професійного розвитку } \\
\text { впродовж життя }\end{array}$ \\
\hline R15G1 & $\begin{array}{l}\text { Особисто для мене зрозуміло, що вчителю вищої категорії та вчителю-початківцю } \\
\text { потрібні різні знання. Та, погодьтесь, вчителі вищої категорії теж всі різні. І одну й ту } \\
\text { ж тему навіть в одному й тому класі кожен з них пояснюватиме по-різному, і урок } \\
\text { проводити, і додаткову літературу шукатиме різну. Мені, наприклад, подобаються одні } \\
\text { посібники, а колега вибирає зовсім інші. Так і з курсами - я піду на одні, а колега - } \\
\text { на інші, хоча працюємо в одній школі. Тут важливо самому розуміти, що тобі потрібно } \\
\text { й для чого. Можна записатись на курси, які видаються цікавими, і на завтра нічого } \\
\text { не застосувати на уроці. Проте для власного розвитку ці курси будуть корисними. } \\
\text { І навпаки теж буває }\end{array}$ & $\begin{array}{l}\text { Здатність здійснювати } \\
\text { моніторинг власної } \\
\text { педагогічної } \\
\text { діяльності і визначати } \\
\text { індивідуальні } \\
\text { професійні потреби }\end{array}$ \\
\hline R5G2 & $\begin{array}{l}\text { Я вважаю, що вчитель самостійно може визначити, що йому вдається, а що - не дуже. } \\
\text { І далі вже приймати рішення, яку літературу почитати, які курси пройти. І ми це завжди } \\
\text { робили, нічого нового тут немає. На початку пандемії у нас більшість педагогів вміла } \\
\text { робити презентації на комп'ютері, ну тести якісь, але потреби в тому не було й умов } \\
\text { не було: у нас не в кожному класі є необхідна техніка, як і у всіх. А коли виникла така } \\
\text { ситуація, що потрібно працювати онлайн - знайшли і ролики на YоuTube, і одне одного } \\
\text { навчили. Хай і не зразу, але прийняли рішення, на якій платформі працювати, щоб дітей } \\
\text { не збивати з толку і розклад мати нормальний. Головне - знати, що треба. І реально } \\
\text { оцінювати наявні ресурси і потреби }\end{array}$ & $\begin{array}{l}\text { Здатність здійснювати } \\
\text { моніторинг власної } \\
\text { педагогічної } \\
\text { діяльності і визначати } \\
\text { індивідуальні } \\
\text { професійні потреби; } \\
\text { здатність застосовувати } \\
\text { інновації у професійній } \\
\text { діяльності }\end{array}$ \\
\hline R8G2 & $\begin{array}{l}\text { Сьогодні постійно виникають нові рішення для дистанційного навчання - } \\
\text { і безкоштовні, і за гроші. Важливо розуміти, що ти можеш використати на практиці, } \\
\text { як поєднати різні онлайн-дошки, наприклад онлайн-тести та Zоот. I чи в тебе техніка } \\
\text { з цим впорається, і чи діти зможуть на своїх телефонах все зробити! Але це тільки } \\
\text { один бік. Інший — як це все наповнити змістом, як пояснити ту ж граматику, вправи } \\
\text { виконати, бо тут потрібно подумати. Біля дошки один розв’язує задачу, всі мають } \\
\text { можливість спостерігати не тільки за написаним, а ще й почути міркування учня. } \\
\text { Важливо, що б така змога була й онлайн. Ну і пояснення матеріалу може бути різним - } \\
\text { хтось подкасти записує, хтось - презентації з голосовими нотатками. Тут вже на учнів } \\
\text { треба дивитись, що ім більше підходить. Ось це і є педагогічна свобода та здатність } \\
\text { застосовувати інновації }\end{array}$ & $\begin{array}{l}\text { Здатність застосовувати } \\
\text { інновації у професійній } \\
\text { діяльності; } \\
\text { здатність застосовувати } \\
\text { різноманітні підходи } \\
\text { до розв’язання проблем } \\
\text { у педагогічній діяльності }\end{array}$ \\
\hline
\end{tabular}


Продовження табл. 3

\begin{tabular}{|c|c|c|}
\hline Респондент & Зміст висловлювання & Компетентність \\
\hline R9G3 & $\begin{array}{l}\text { У мене, як і у всіх, були проблеми з частиною учнів через те, що вони не мали вдома } \\
\text { достатньо техніки для онлайн-уроків. І тут справді важливо мати кілька варіантів, щоб } \\
\text { запропонувати ї дітям. До того ж я теж повинна мати достатньо часу, аби підготувати } \\
\text { такі варіанти для кожного уроку, для кожного класу. І тут питання не тільки до мене - } \\
\text { чи можу я? Тут питання ще і до держави - а в мене є час, щоб навчитись, розробити } \\
\text { різні варіанти для різних гаджетів і ще й не вигоріти? Оце про інновації та час для них }\end{array}$ & $\begin{array}{l}\text { Здатність застосовувати } \\
\text { різноманітні підходи } \\
\text { до розв’язання проблем } \\
\text { у педагогічній діяльності }\end{array}$ \\
\hline R11G3 & $\begin{array}{l}\text { Погоджуюсь, що часу реально не вистачає на все. Але професійний розвиток - це } \\
\text { умова роботи вчителя. Не будеш навчатись, розвиватись, не будеш шукати інші } \\
\text { рішення, бо умови змінились, як сьогодні з карантином - учні не матимуть гарних } \\
\text { результатів. Важливо, коли знайшов якусь нову ідею, спробував, як вона працює, - } \\
\text { подивитись на результати. Якщо це на користь дитині й забирає менше ресурсів } \\
\text { і в учня, і в учителя - чудово. Якщо комусь шкодить - навіщо воно потрібне взагалі. } \\
\text { Ну і буває так, що у колег працює, всі задоволені, а у тебе - не йде. То потрібно мати } \\
\text { час, щоб зупинись і подумати, а що я роблю не так? І це справді безперервний процес. } \\
\text { Аби тільки час на це не забирати від власної родини }\end{array}$ & $\begin{array}{l}\text { Здатність застосовувати } \\
\text { різноманітні підходи } \\
\text { до розв'язання } \\
\text { проблем у педагогічній } \\
\text { діяльності; } \\
\text { здатність здійснювати } \\
\text { моніторинг власної } \\
\text { педагогічної } \\
\text { діяльності й визначати } \\
\text { індивідуальні } \\
\text { професійні потреби }\end{array}$ \\
\hline
\end{tabular}

Як видно з табл. 3, під час дискусії респонденти апелювали не лише до змісту обговорюваної трудової функції, а й постійно спиралися на досвід, набутий як раніше, так і в нових для всіх умовах пандемії, вимушеного впровадження дистанційного навчання та прискореного опанування новими для них технологічними рішеннями. Вважаємо за необхідне зазначити, що в кожній із груп дискусія продовжувалася навіть після завершення відведеного часу та припинення запису.

Інтерпретація результатів. Респонденти активно обговорювали прояви тієї чи тієї компетентності трудової функції «безперервний професійний розвиток» у контексті глобальних змін у діяльності системи освіти, які відбулися в 2020 р. Це свідчить не лише про попередню підготовку до опитування, а й про зацікавленість у предметі дискусіі. У відповідь на запитання, чи потрібно включати таку функцію в професійний стандарт, більшість учасників відповіла схвально в тій чи тій формі. Разом з тим переважна більшість (близько $90 \%$ ) погоджувалась із твердженнями окремих респондентів стосовно того, що така трудова функція - це вимога не лише до вчителя, а й до роботодавця, який має забезпечити всі необхідні умови: доступ до якісних курсів підвищення кваліфікації, у тому числі й оплату; наявність необхідного обладнання на робочому місці та вдома; виокремити в навантаженні вчителя спеціальний час для професійного розвитку, оскільки 3 переходом на онлайн педагоги втратили можливість навчатися з відривом від посадових обов'язків, що призводить до подвійного навантаження.

Предметом активного обговорення став зміст компетентності «здатність до навчання впродовж життя». Респонденти зазначали, що розмежування вимог до кваліфікаційних категорій педагогів - цілком логічний крок, однак ситуація в закладах освіти свідчить про те, що навіть молоді педагоги мають чим поділитись 3 колегами та навчити старших, особливо з огляду на рівень володіння IKT. При цьому педагоги-початківці часто не усвідомлюють власні проблеми - 3 рівнем володіння методикою навчання, соціальноемоційною компетентністю тощо. I саме 3 цієї причини потрібно створити інструмент для самооцінювання рівня професійної компетентності та оцінювання останньої іншими (колегами, експертами, адміністрацією закладу тощо).

Результати проведеного опитування у форматі фокус-груп засвідчили таке:

- певні утруднення викликає розуміння терміна «трудова функція», які знімаються після грунтовного ознайомлення 3 нормами чинного законодавства та підходами до розроблення стандартів професійної діяльності;

- педагогічна спільнота в цілому позитивно оцінює структуру означеної трудової функції та перелік компетентностей, які включені розробниками до їі змісту;

- включення до структури трудової функції «безперервний професійний розвиток» інноваційної компетентності, яке зумовило різні оцінки під час обговорення в соціальних мережах, не викликало негативних реакцій та оцінок у респондентів;

- на думку респондентів, позитивним у документі $€$ чіткий розподіл рівнів прояву кожної компетентності, що входить до структури трудової функції, за кваліфікаційними категоріями;

- учасники обговорення наголошували на існуванні певних ризиків з огляду на те, що норми професійного стандарту матимуть односторонній характер, тобто трактуватимуться лише як нові вимоги до вчителя та не враховуватимуть зміну вимог до роботодавця;

- професійний стандарт може стати основою для створення інструментів для (само) оцінювання рівня професійної компетент- 
ності; визначення освітніх потреб педагогів; розроблення індивідуальної професійної освітньої траєкторії; програм корпоративного навчання для педагогічних колективів; створення нового Положення про атестацію педагогічних працівників; перегляду змісту посадових інструкцій, їх уніфікації та індивідуалізації з урахуванням особливостей професійної діяльності та кваліфікаційної категорії педагогів;

- практично всі респонденти відзначили, що зміст всього документа та сутність кожної окремої трудової функції потрібно донести до цільової аудиторії - вчителів та засновників закладів загальної середньої освіти шляхом широкої інформаційної кампанії.

Результати проведеного теоретичного та емпіричного дослідження засвідчили, що запропонований розробниками для громадського обговорення проєкт Професійного стандарту в цілому оцінюється педагогами як важливий документ, що може застосовуватись з метою визначення цілей і завдань безперервного професійного розвитку вчителя та гармонізувати права й обов'язки кожного окремого педагога, адміністрації закладу освіти, педагогічної ради, яка має повноваження щодо визнання результатів підвищення кваліфікації та засновників закладів загальної середньої освіти.

Крім того, такий інструмент допоможе не тільки спроєктувати індивідуальну професійну освітню траєкторію для кожного педагога в школі, а й розробити програму корпоративного навчання в кожному окремому закладі освіти, сформувати освітнє замовлення для суб’єктів підвищення кваліфікації педагогічних працівників закладів загальної середньої освіти.

Висновки. Поширення результатів дослідження на всю сукупність педагогічних працівників України обмежувалося насамперед розміром вибірки та метою дослідження, яка звужувалася виявленням особливостей розуміння змісту трудової функції «безперервний професійний розвиток» і сприйняття запропонованих розробниками компетентностей, що входять в її структуру. Крім того, важливим був загальний контекст обговорення: ставлення до документа в цілому, можливість та межі його імплементації в практику діяльності системи освіти України тощо.

Проведене теоретичне дослідження та опитування у форматі фокус-груп не вичерпує всі можливі аспекти, пов'язані 3 трактуванням сутності й змісту трудової функції «безперервний професійний розвиток», однак свідчить про те, що така трудова функція не сприймається педагогічною спільнотою як штучне утворення чи додаткова вимога. Утім, респонденти зазначили, що адміністрація та засновники закладу освіти повинні забезпечити належні умови для виконання вчителем всього комплексу визначених документом трудових функцій. Одним із напрямів подальших наукових досліджень може стати вивчення результатів застосування професійного стандарту вчителя з метою проєктування індивідуальної професійної освітньої траєкторії вчителя та програм розвитку професійної компетентності педагогічного персоналу закладу загальної середньої освіти.

\section{ДЖЕРЕЛА}

1. Bubb S., Earley P. Leading and Managing Continuing Professional Development. London: SAGE Publications, 2007. 188 р. DOI 10.4135/9781446216637.

2. Бойко М.Д. Трудове право. К.: Олан, 2002. 345 с.

3. Гевел О. Трудова функція та порядок її визначення. Право України. 2002. № 4. С. 89-93.

4. Енциклопедія освіти / гол. ред. В.Г. Кремень. К.: Юрінком Інтер, 2008. 1040 с.

5. Івашньова С.В. Супервізія в діяльності освітнього тренера. Наукові записки Ніжин. держ. ун-ту ім. М. Гоголя. Психолого-педагогічні науки. 2018. № 3. С. 96-106.

6. Івашньова С.В. Як провести супервізію тренерської роботи. К.: Вид-во Київ. ун-ту ім. Б. Грінченка. 2020 p. 96 c.

7. Ілляхова М. Безперервний професійний розвиток науково-педагогічних працівників у контексті розвитку європейського освітнього простору. Вісник Наи. ун-ту «Чернігівський колегіум» ім. Т.Г. Шевченка. Серія: Педагогічні науки. 2019. Вип. 1. С. 55-60. URL: https://visnyk.chnpu.edu.ua/ download/vs157/13.pdf (дата звернення: 09.12.2020).

8. Коваленко Р.І. Значення трудової функції при прийнятті на роботу. Наук. вісник Міжнар. гуманіт. ун-ту. Серія: Юриспруденція. 2014. № 12, т. 2. С. 92-94.

9. Костюченко О.Є. Питання трудової функції працівника в проекті Трудового кодексу. Форум права. 2009. № 3. С. 355-359.

10. Лавріненко О.В. Трудова функція працівника як обов'язкова умова трудового договору: теоретико-прикладні аспекти та шляхи вдосконалення загального й спеціального законодавства України про працю. Форум права. 2009. № 1. С. 301-328.

11. Національний класифікатор України. ДК 003:2010 «Класифікатор професій». База даних «Законодавство України» / ВР України. URL: https://zakon.rada.gov.ua/rada/show/va327609-10\#Text (дата звернення: 10.12.2020). 
12. Про освіту: Закон України від 05.09.2017 р. № 2145-VIII. База даних «Законодавство України» / BP України. URL: https://zakon.rada.gov.ua/laws/ show/2145-19 (дата звернення: 10.12.2020).

13. Раскалінос В. Рефлексивна компетентність як складова професійної характеристики майбутнього фахівця. Проблеми підготовки сучасного вчителя. 2011. № 4, ч. 1. С. 176-182.

14. Степанов С.Ю., Полищук О.А. Рефлексивная компетентность как базовая категория предпринимательской деятельности. Рефлексия, образование и интеллектуальные инновации. Новосибирск: НГУ, 1995. С. 266-271.

\section{REFERENCES}

1. Bubb, S., Earley, P. (2007). Leading and Managing Continuing Professional Development. SAGE Publications. 188 p. [in English].

http://dx.doi.org/10.4135/9781446216637

2. Boiko, M. D. (2002). Trudove pravo [Labor Law]. Olan. 345 p. [in Ukrainian].

3. Hevel, O. (2002). Trudova funktsiia ta poriadok yii vyznachennia [Labor Function and the Procedure for Its Definition]. Pravo Ukrainy, 4, 89-93 [in Ukrainian].

4. Entsyklopediia osvity. (2008). [Encyclopedia of Education]. Hol. red. V. H. Kremen, Yurinkom Inter, 1040 [in Ukrainian].

5. Ivashnova, S. V. (2018). Superviziia v diialnosti osvitnioho trenera [Supervision in the Activities of an Educational Coach]. Naukovi zapysky Nizhyn. derzh. un-tu imeni Mykoly Hoholia. Psykholohopedahohichni nauky, 3, 96-106 [in Ukrainian].

6. Ivashnova, S. V. (2020). Yak provesty superviziiu trenerskoi roboty [How to Supervise Coaching Work]. Vyd-vo Kyiv. un-tu imeni Borysa Hrinchenka, 96 [in Ukrainian].

7. Illiakhova, M. (2019). Bezperervnyi profesiinyi rozvytok naukovo-pedahohichnykh pratsivnykiv u konteksti rozvytku yevropeiskoho osvitnioho prostoru [Continuous Professional Development of Scientific and Pedagogical Workers in the Context of the Development of the European Educational Environment]. Visnyk Nats. un-tu "Chernihivskyi kolehium” imeni T. H. Shevchenka. Seriia: Pedahohichni nauky, 1, 55-60 [in Ukrainian].

https://visnyk.chnpu.edu.ua/download/vs157/13.pdf

8. Kovalenko, R. I. (2014). Znachennia trudovoi funktsii pry pryiniatti na robotu [Value of Job Function in Hiring]. Nauk visnyk Mizhnar. humanit. un-tu. Seriia: Yurysprudentsiia, 12 (2), 92-94 [in Ukrainian].

9. Kostiuchenko, O. Ye. (2009). Pytannia trudovoi funktsii pratsivnyka v proekti Trudovoho kodeksu [Issues of Labor Function of the Employee in the Draft Labor Code]. Forum prava, 3, 355-359 [in Ukrainian].

10. Lavrinenko, O. V. (2009). Trudova funktsiia pratsivnyka yak oboviazkova umova trudovoho dohovoru: teoretyko-prykladni aspekty ta shliakhy vdoskonalennia zahalnoho y spetsialnoho zakonodavstva Ukrainy pro pratsiu [Labor Function of the Employee as a Mandatory Condition of the Employment Contract: Theoretical and Applied Aspects and Ways to Improve General and Special Legislation of Ukraine on Labor]. Forum prava, 1, 301-328 [in Ukrainian].

11. Natsionalnyi klasyfikator Ukrainy. DK 003:2010 "Klasyfikator profesii" [National Classifier of Ukraine. DK 003: 2010 “Classifier of Professions”]. Baza danykh “Zakonodavstvo Ukrainy”, VR Ukrainy [in Ukrainian].

https://zakon.rada.gov.ua/rada/show/va327609-10\#Text

12. Pro osvitu: Zakon Ukrainy vid 05.09.2017 r. № 2145-VIII. Baza danykh “Zakonodavstvo Ukrainy" [On Education: Law of Ukraine of 05.09.2017 № 2145-VIII]. VR Ukrainy [in Ukrainian].

https://zakon.rada.gov.ua/laws/ show/2145-19

13. Raskalinos, V.(2011). Refleksyvna kompetentnist yak skladova profesiinoi kharakterystyky maibutnoho fakhivtsia [Reflexive Competence as a Component of the Professional Characteristics of the Future Specialist]. Problemy pidhotovky suchasnoho vchytelia, 4 (1), 176-182 [in Ukrainian].

14. Stepanov, S. Yu., Polishhuk, O. A. (1995). Refleksivnaia kompetentnost kak bazovaia kategoriia perdprinimatelskoi deiatelnosti [Reflexive Competence as a Basic Category of Entrepreneurial Activity]. Refleksiia, obrazovanie i intellektualnyie innovatsii, 266-271 [in Russian].

\section{Ивашнёва С. НЕПРЕРЫВНОЕ ПРОФЕССИОНАЛЬНОЕ РАЗВИТИЕ КАК ТРУДОВАЯ ФУНКЦИЯ ПЕДАГОГА}

Статья представляет результаты теоретического (содержания и сущности понятия «трудовая функция») и эмпирического исследования (опроса педагогов в формате фокус-групn). Анализ сути понятия «непрерывное профессиональное развитие» и динамики его изменений в течение профессиональной жизни педагога позволил выделить ведущие компетентности, которые включены в содержание 
трудовой функции. Обсуждение содержания и сущности трудовой функции «непрерывное профессиональное развитие» в фокус-группах продемонстрировало наличие некоторых затруднений у респондентов при определении сути основных компетентностей. Опрос выявил также оценки респондентами существования определенных рисков того, что нормы профессионального стандарта будут трактоваться исключительно как новые требования к учителю и не учитывать изменение требований к работодателю, обязанного обеспечить условия для реализации данной трудовой функции.

Ключевые слова: непрерывное профессиональное развитие, способность к обучению в течение жизни, компетентность, профессия, реслективная компетентность, трудовая функция.

\section{S. Ivashnova \\ CONTINUOUS PROFESSIONAL DEVELOPMENT AS A LABOR FUNCTION OF A TEACHER}

The article presents the results of theoretical (content and essence of the concept of "labour function") and empirical research (survey of teachers in the format of focus groups). Analysis of the content of the concept of "continuous professional development" and the dynamics of its changes during the teacher's professional life made it possible to identify the leading competencies that are included in the content of the labour function. Discussion of the content and essence of the labour function "continuous professional development" in focus groups demonstrated some difficulties that the respondents experience in determining the content of the main competencies.

The survey also revealed the respondents' assessments of the existence of certain risks that the norms of the professional standard will be interpreted exclusively as new requirements for the teacher and will not take into account the changes in the requirements for the employer, who is obliged to provide conditions for the implementation of this labour function. The conducted research has confirmed the relevance of the development of the professional standard for teachers and revealed the need for additional explanatory work in the professional environment. The respondents also pointed out that the introduction of this document into practice can become the basis for designing an individual professional educational trajectory for a teacher and creating plans for corporate training for teaching teams. Further research is required by the introduction of a draft professional standard, including a possible revision of the activities of the advanced training system.

Key words: continuous professional development, ability to learn throughout life, competence, profession, reflective competence, labour function.

Стаття надійшла до редакції 12.12.2020 p.

Прийнято до друку 24.12.2020 p. 